\title{
Büyükşehir Belediyeleri Web Sitelerinin Covid-19 Salgın Sürecinde Diyalojik İletişim Açısından Değerlendirilmesi
}

\author{
Aynur Arslan (Dr. Öğr. Üyesi) \\ iD Ondokuz Mayıs Üniversitesi Sağlık Bilimleri Fakültesi \\ aynur.arslan@omu.edu.tr
}

Başvuru Tarihi: 29.07.2021

Yayına Kabul Tarihi: 24.09.2021

Yayınlanma Tarihi: 28.10.2021

https://doi.org/10.17680/erciyesiletisim.976261

\section{Öz}

Günümüzde belediye-vatandaş iletişimi kurumsal web siteleri üzerinden dijital bir boyuta taşınmıștır. Belediyeler hedef kitleleri ile; internet ve web siteleri üzerinden daha hızlı, kolay ve etkili iletişim kurabilmektedirler. Web siteleri aynı zamanda vatandaşların sorun, talep, beklenti, tercih ve görüşlerini belediyeye iletebilecekleri diyalojik bir ortam da sunar. 11 Mart 2020 tarihinde küresel bir salgın olarak ilan edilen Covid-19 pandemisinin neden olduğu kriz ortamında evinden çıkamayan vatandaş için belediye ile iletişim kurmanın en hızlı ve en kolay yollarından biri web siteleri olmuştur. Bu çalışmada Türkiye'deki 30 büyükșehir belediyesinin web siteleri, 01-31 Mart 2021 tarihleri arasında, Covid-19 salgın sürecinde, diyalojik iletişim aracı olma özelliklerini taşıyıp taşımadıkları açısından Kent ve Taylor'un diyalojik iletişim teorisi bağlamında incelenmiştir. Çalışmada ayrıca büyükşehir belediyeleri web sitelerinin Covid-19 salgınına ait içeriklerine de bakılmıștır. Çalışmanın sonucunda elde edilen bulgular büyükşehir belediyeleri web sitelerinin daha çok tanıtma amaçlı kullanıldığını, diyalojik iletişim özelliklerinin ise yetersiz olduğunu göstermiştir. Ayrıca web sitelerinin Covid-19 salgını hakkındaki içeriklerine bakıldığında, çoğunlukla belediyelerin salgın sürecindeki faaliyetlerine ait haberlerin yer aldığı, devam eden salgın sürecine ilişkin diyalojik bir içeriğin sunulmadığı da saptanmıştır.

Anahtar Kelimeler: Halkla İlişkiler, Büyükşehir Belediyeleri, Kurumsal Web Siteleri, Diyalojik İletişim, Covid-19 Salgını. 


\title{
Evaluation of Metropolitan Municipalities' Websites in terms of Dialogic Communication during the Covid-19 Pandemic
}

\author{
Aynur Arslan (Asst. Prof. Dr.) \\ iD Ondokuz Mayıs University Faculty of Health Sciences \\ aynur.arslan@omu.edu.tr
}

Date Received: 29.07.2021

Date Accepted: 24.09.2021

Date Published: 28.10 .2021

https://doi.org/10.17680/erciyesiletisim.976261

\begin{abstract}
Today, municipal-citizen communication reached a digital level through corporate websites. The websites offer a dialogic environment in which citizens can communicate their problems, demands, expectations, preferences and opinions to the municipality. In the crisis environment caused by the Covid-19 pandemic, which was declared a global epidemic on March 11, 2020, web-sites are one of the fastest and easiest ways to reach municipalities for citizens. In this study, the web sites of 30 metropolitan municipalities in Turkey were examined between March 1-31 2021, in the context of Kent and Taylor's dialogic communication theory in terms of whether they were means of dialogic communication during the Covid-19 pandemic. The study also reviewed the metropolitan municipalities' websites content related to the Covid-19 pandemic. The results of the study showed that metropolitan municipalities' websites were rather used for publicity purposes, and their dialogic communication features were insufficient. The study also revealed that the websites' content related to the Covid-19 pandemic was consisting of news about the municipality's activities during the pandemic, and no dialogic content about the ongoing pandemic process was given.
\end{abstract}

Keywords: Public Relations, Metropolitan Municipalities, Corporate Websites, Dialogic Communication, Covid-19 Pandemic. 


\section{Giriş}

Bilgi ve iletişim teknolojilerindeki gelişmeler internet ve World Wide Web (www) kullanımının bütün dünyada hızla yaygınlaşmasını sağlayarak örgüt-kamu ilişkilerinde küresel bir dönüşüm sürecini başlatmıştır. Giderek daha fazla sayıda birey ve işletmenin ilişkilerini elektronik iletişim araçlarıyla yürütmeye başlaması, örgütlere kamu kategorileri ile aralarındaki ilişkileri geliştirebilmek için yeni olanaklar sunmuştur (Özdemir \& Yamanoğlu, 2010, s. 6). Tüm dünyada yaşanan dönüşüm Türk kamu yönetiminde de etkilerini göstermiş ve devlet-vatandaş ilişkisinde, doğrudan, yenilikçi, daha düşük maliyetle, daha kaliteli hizmet imkânı sağlayan elektronik devlet (e-devlet) uygulamalarına geçilmiştir (Dunleavy, Margetts, John, \& McCarthy, 1999, s. 9). E-devlet uygulamaları; devletin vatandaşlara verdiği hizmetleri elektronik ortamda sunmasıdır (Çarıkçı, 2010, s. 98). Kamu yönetiminde elektronik devlete dönüşümün ilk adımlarından biri, kamu kurumlarına ait resmi web siteleridir. Dönüşümün ilk yıllarında web siteleri üzerinden tek yönlü bilgi aktarımının yapılması, etkileşimli bir hizmet sunumuna olanak vermemişse de günümüzde dijital teknolojideki ilerlemeler devlet-vatandaş ilişkisinin diyalojik bir düzlemde gerçekleşmesini sağlayan araç ve uygulamaların kullanılmasına olanak tanımaktadır (Tarhan, 2011, s. 32-33). Kent ve Taylor'a (1998, s. 325) göre diyalojik iletişim karşılıklı fikir ve görüşlerin tartışılmasını ve paylaşılmasını ifade eder. Kamu yönetiminde halkla ilişkiler çalışmalarının hedeflerinden biri de yöneten ve yönetilen arasında diyalojik iletişim ortamını oluşturabilmektir. Kurumsal web siteleri halkla ilişkilerin bu hedefi için en uygun araçlardan biridir. Web siteleri, kurumların dışa açılan yüzü olarak hedef kitlenin kuruma ait bir takım bilgi ve belgelere erişilmesi, basınla olan ilişkiler, şeffaflık ve etkileşim olanakları ile diyalojik ilişkiye ortam sağlarlar (Yaşar \& Altıncık, 2018, s. 225). Bu bağlamda web sitelerinin kurumsal tanıtım amaçlı içeriklerinin yanında hedef kitlenin daha yakından araştırılmasını, beklentilerinin öğrenilmesini, katılımın teşvik edilmesini, fikir ve görüşlerin karşılıklı paylaşılmasını sağlayacak diyalojik araç ve uygulamaları da içermesi gerekmektedir (Özdemir \& Yamanoğlu, 2010, s. 28).

Kamu hizmeti sunumunda halka en yakın birim olan belediyeler, halkın günlük yerel ihtiyaçlarının giderilmesinden birinci derecede sorumludurlar. Seçimle iş başına gelen yönetimler olarak belediyeler başarılı olabilmek için halkın onayını almak zorundadırlar. Vatandaşın istek ve ihtiyaçlarına duyarlı olan, onlarla etkileşim kurabilen, karar süreçlerine ortak eden, dinleyen kısaca halkla iç içe olan belediyelerin başarılı olması daha kolaydır (Akyıldız, 2012, s. 4422). Belediyelerin kendilerini halka tanıtmak ve halkı tanımak için halkla ilişkiler uygulama ve araçlarını en doğru şekilde kullanmaları gerekir. $\mathrm{Bu}$ amaçla halkla ilişkiler çalışmalarında kullanılan önemli araçlardan biri de kurumsal web siteleridir. Belediyeler hedef kitleleriyle web siteleri üzerinden daha hızlı, kolay ve etkili iletişim kurabilmekte, kurum tanıtımı, hizmet ve faaliyetler hakkında bilgilendirme yapabilmekte ve birçok hizmeti e-belediye uygulamaları ile dijital ortamda güvenli bir şekilde verebilmektedirler. Özellikle kriz dönemlerinde kurumsal web siteleri, hem kurum hem de halk için hızlı ve etkileşimli bir iletişim ortamı sunması sebebiyle sorunların çözülmesi ya da en az hasarla atlatılmasına büyük katkı sağlar (Grier \& Moreland, 2003, s. 429). Web siteleri aynı zamanda vatandaşların sorun, talep, beklenti, tercih ve görüşlerini belediyeye iletebilecekleri diyalojik bir ortam da sunmaktadır.

Belediyelerin başarısı hizmet verdikleri halkı ve ihtiyaçlarını iyi tanımalarına ve onlarla kurdukları etkileşimin gücüne bağlıdır. Belediyeler kamu yararına hizmet sunarken temel hizmetlerin elde edilmesinde her vatandaşa eșit hak tanımak, sosyal ve ekonomik 
yoksunluk düzeyinde olanları korumak, olağanüstü süreçlerde halkın yerel ihtiyaçlarına çözüm üretmek ve onlara sağlıklı yaşam koşulları oluşturmakla yükümlüdürler (Arslan, 2016, s. 80). 11 Mart 2020 tarihinde Dünya Sağlık Örgütü tarafından küresel bir salgın olarak ilan edilen ve hızla yayılan Covid-19 pandemisiyle mücadelede de yerel önlemlerin önemi ortaya çıkmış ve yerel yönetim birimleri olarak belediyelerin sorumlulukları artmıştır. Salgın dolayısıyla evde kalmak zorunda olan, çeşitli kısıtlamalar nedeniyle engellenen vatandaşların başta sağlık, eğitim, sosyal yardım, beslenme, temizlik gibi birçok ihtiyacına belediye hizmetleri dahilinde çözüm üretmek, salgının yayılmasını önlemek için alınan tedbirlerin uygulanmasını desteklemek belediyelerin öncelikli görevleri haline gelmiştir. Bu süreçte evinden çıkamayan vatandaş ile belediye arasında iletişim kurmanın en önemli ve en kolay yollarından biri web siteleri olmuştur.

Bu çalışmanın amacı Türkiye'deki 30 büyükşehir belediyesinin Covid-19 salgın döneminde web sitelerini hedef kitleleriyle etkileșim kurabilmek ve ilișki geliştirebilmek amacıyla diyalojik iletişim aracı olarak nasıl kullandıklarını ortaya koymaktır. Kriz döneminde belediye-vatandaş etkileşiminin güçlü olması krizin daha az hasarla atlatılmasını ve kamuoyunun güveninin kazanılmasını sağlar. Bu nedenle yerel yönetimler için halkla doğrudan iletişim kurulmasını sağlayan ve bu noktada her iki taraf için de büyük bir avantaj olan kurumsal web sitelerinin doğru yönetilmesi ve amaca uygunluğunun sık sık denetlenmesi gerekir (Fogli \& Guida, 2015, s. 52). Bu çalışma büyükşehir belediyelerinin Covid-19 salgın sürecinde kurumsal web siteleri üzerinden hedef kitleleriyle kurdukları iletişimin diyalojik özelliklerini yeniden değerlendirmelerine katkı sağlayacaktır.

\section{Diyalojik İletişim Aracı Olarak Kurumsal Web Siteleri}

İnternet üzerinden veri paylaşımını sağlayan World Wide Web (www), Avrupa Nükleer Araştırma Merkezi'nde (CERN) yazılım mühendisi olarak çalışan Tim Berners-Lee tarafından 1990 yılında yazılmış ilk web sunucusudur. World Wide Web için hazırlanıp düzenlenen ve web tarayıcıları aracılığıyla görüntülenen dokümanlara web sayfası denir. Birden çok web sayfasının yani çok sayıda içeriğin bir araya gelmesiyle de web siteleri oluşur. Web siteleri, kullanıcıların web ağına bağlanarak web tarayıcıları üzerinden görüntüledikleri hipermetin dosyalarıdır (Kılıçer, 2018, s. 6). Peltekoğlu'na (2007, s. 311) göre ise web siteleri; ait oldukları kurum ya da kişinin kendini en iyi, en hızlı ifade etmesine olanak sağlayan ve gereksinim duyulan bilgilerin en doğru biçimde sınıflandırılarak oluşturulduğu, sınırı olmayan sayfaların bileşkesidir. Günümüz dünyasında önemli bir kurumsal iletişim aracı olan web siteleri sadece sanayi ve ticaret alanında değil, aynı zamanda devlet idareleri, finansal hizmetler, sağlık hizmetleri, eğlence, kültür ve daha birçok sektör için kuruluşların başarısında etkili halkla ilişkiler aracıdır (Fogli \& Guida, 2015, s. 52). Web siteleri metin, ses, görüntü, hareket ve gerçek zamanlı etkileşim potansiyelini tek bir pakette birleştirme özelliğine sahiptir. Kitap, dergi ve gazetenin ses, hareket veya gerçek zamanlı etkileşim kapasiteleri yoktur. Benzer şekilde, radyo ve televizyon da gerçek zamanlı etkileşim kapasitesine sahip değildir. $\mathrm{Bu}$ nedenle web sitelerinin birçok açıdan geleneksel kitle iletişim araçlarından üstün özelliklere sahip olduğu söylenebilir.

Kurumsal web siteleri, esas olarak kurumu müşteriler, yatırımcılar veya basın gibi dış paydaş gruplara tanıtmak amacıyla kurum tarafından yapılandırılan web siteleri olarak tanımlanır (Pollach, 2011, s. 27). Kurumsal web siteleri müşteriler, satıcılar, çalışanlar, iş arayanlar, yatırımcılar, finansal analistler, gazeteciler, öğrenciler, araştırmacılar ve genel olarak halk dahil olmak üzere tüm potansiyel takipçilere sınırsız miktarda bilgi iletme yeteneğine sahiptir. Ayrıca kurumlara hedef kitlelerine gönderdikleri mesajların eşik 
bekçileri tarafından filtrelenmeden, yalnızca kurumun kendi yönetimi tarafından kontrol edilerek gönderilme avantajı da sağlar. Web sitelerine ziyaretçileri şirketle diyaloğa girmeye teşvik etmek için etkileșimli özellikler eklenebilir ve böylece kurumların hedef kitleleri hakkında daha fazla bilgi edinmeleri de sağlanabilir (Pollach, 2005, s. 286). Bu anlamda web siteleri halkla ilişkiler açısından hedef kitlelerin görüş, öneri ve taleplerini tespit etmek, halkı tanımak ve kurumu tanıtmak için, ilişki geliştirmeye imkân sağlayan ideal araçlardır denilebilir (Kent, Taylor, \& White, 2003, s. 63-77).

Örgütsel iletişim alanında kullanılan dijital uygulamalara her geçen gün yenileri eklense de kurumsal web siteleri önemini korumaya devam etmektedir. İnternet Live Stats'in Haziran 2021 verilerine göre dünyada web sitesi sayısı 1 milyar 876 milyon civarındadır (2021). Oldukça kalabalık ve rekabetçi olan bu ortamda kurumların web içeriklerini farklılaştırmaları, yeni özelliklerle zenginleştirmeleri ve sitelerini ilgi çekici hale getirmeleri gerekmektedir. Farklı hedef kitlelere yönelik planlanmıș iletişim uygulamaları, farklı bilgilendirmeler, belirli stratejiler bağlamında hazırlanmış materyaller (Mengü, 2016, s. 299), kurumların kişiliklerini, değerlerini, vaatlerini ortaya koyarak rakiplerinden farklılaşmalarını sağlayacak içerikler web sitelerini zenginleştirecektir. Ayrıca web sitesinin etkileşime izin veren özelliklere sahip olması, kurumların hedef kitlelerini daha iyi tanımalarına ve doğru stratejiler geliştirmelerine de firsat sağlar. Kurumlar web siteleri üzerinden hedef kitleleriyle hızlı, aracısız, zamansız ve kontrolün kendi ellerinde olduğu bir ilişki kurabilirler. Böylece tanıtma faaliyetleri kadar tanıma faaliyetlerini de güçlendirerek güven kazanabilirler. Bu bağlamda kuruluşların hedef kitleleriyle diyalojik iletişim kurabilecekleri koşulları hazırlamıș olmaları gereklidir

Kurumsal web sitelerinin en stratejik kullanım alanlardan biri de kriz dönemleridir. Web siteleri kriz durumlarında acil ve ilk müdahale için en etkili iletişim araçlarından biridir. Kriz durumlarında kurumlar öncelikle kendi web sitelerini kriz iletişimi için merkezi platform olarak kullanmalıdırlar. Çünkü, kriz zamanlarında bilgi arayan kullanıcıların ilk adresi kurumsal web siteleridir. Kuruluş tarafından hazırlanması ve içeriğin kontrol edilmesi, hem genel halk hem de medya için doğrulanabilir bilgi kaynaklarının oluşturulmasına izin vermesi kurum için bir avantaj sağlar (Cavalic, 2017). Krizin çıkma sebebi ne olursa olsun, olağan durumlar için hazırlanmış web sitelerinin içeriği eğer yeterliyse, kriz yönetimine ve bilgilendirmeye hızla başlamak gerekir. Ancak web sitesi yeterli değilse, kriz durumuna özel yeni bir web sitesi ya da sayfasının acil olarak hazırlanması gereklidir (Akdağ \& Taşdemir, 2006, s. 153). Güçdemir'e (2010) göre kriz durumlarında kurumlar web ortamını 7/24 izlemeli, gerekirse kriz anında basit bir isimle yeni bir sayfa açılmalı, kriz takımında bir bilişim veya web uzmanı bulundurmalı, kurumsal web sitesinde bağımsız kaynakların linkleri olmalı, bilgiler mutlaka güncel olmalı, online bir platform oluşturarak gelen sorular anında cevaplandırılmalıdır. Kriz durumunda web sitesindeki bilgilerin bütün hedef kitle için yeterli, güvenilir ve güncel tutulması ve hedef kitlelerle diyaloğun kesintisiz devam etmesi gerekir. Kriz dönemlerinde diyalojik iletişim kurmaya açık ve istekli olan kuruluşlar hedef kitleleri tarafın daha olumlu algılanır (Camilleri, 2021). Hedef kitlesini kriz dönemlerinde yalnız bırakmayan diyalojik ilişkiyi sürdüren kuruluşlar, itibar oluşturmak için bunu bir firsata da dönüştürebilirler.

Günümüzün küresel krizi Covid-19 pandemisi de; toplumsal hayatın siyasi, ekonomik, kültürel bütün alanlarında ve iletişim süreçlerinde etkisini göstermiş, kurum ve kuruluşların hedef kitle katılımlarını etkilemiştir. Bu süreçte kurumların halkla ilişkiler departmanları benzeri görülmemiş bir çalıșma ile bu durumu karșılamaya çalışmışlardır (Camilleri, 2021). Pandeminin başlangıcındaki kaos, belirsizlik, güvenilir olmayan bilgiler 
nedeniyle yaşanan gerilimi kontrol altına almak için iletişimi sürekli tutmak, doyurucu açıklamalar yapmak ve geri bildirime imkân sağlayan bir ortam hazırlamak gerekliydi. Bütün dünyada hükümetler, kurumlar, işletmeler ve medya dahil olmak üzere kuruluşlar, web siteleri ve diğer dijital ortamlardan, halka maske kullanımı, sosyal mesafe ve hijyen uygulamaları hakkında faydalı bilgiler verip, süreçle ilgili yeni düzenlemeleri duyurarak vatandaşları sakin olmaya ve önleyici tedbirlere uymaya teşvik ettiler. Salgın nedeniyle seyahat etmesi yasaklanan, evde kalması istenen hatta buna zorlanan halk için kurumlarla iletişim kurabilmenin en hızlı ve en kolay yollarından biri kurumsal web siteleri olmuştur (Camilleri, 2021). Web siteleri kriz durumlarında kurumların halkla ilişkiler çalışmalarında diyalojik ilişkinin kurulmasına fırsat sağlayan iletişim ortamlarıdır.

Halkla ilişkilerde diyaloğa dayalı ilişkiyi desteklemek, ilişki geliştirmenin ve güçlendirmenin yollarından biridir. Kurumlar açısından diyalog, birey ve gruplarla açık iletişim kurulmasını ve kamu kategorilerinin örgütle iletişimsel olarak eşit duruma yükselmesini ifade eder, (Yağmurlu, 2013, s. 99; Özdemir \& Yamanoğlu, 2010, s. 6). Kent ve Taylor (1998, s. 325), kurumlar için diyalojik iletişimin önemini vurguladıkları çalışmalarında, kurumların web siteleri üzerinden hedef kitleleri ile diyalojik iletişim geliştirmelerine ve sürdürmelerine rehberlik eden teorik bir çerçeve sunmuşlardır. Diyalojik İletişim Teorisinin öncüleri olan Kent ve Taylor'a (1998, s. 325) göre iletişimsel bir alışverişi ifade eden diyalog, iki temel ilke ile açıklanabilir. İlk olarak, diyaloğa katılan bireylerin mutlaka aynı fikirde olmaları gerekmez. Ancak, karşılıklı olarak tatmin edici bir sonuca ulaşma çabası vardır. Tartışmacıların mutlaka anlaşmaya varmaları beklenmez, diyalog sadece anlaşma ile ilgili değildir. Burada beklenen açık bir fikir alışverişi sürecinin gerçekleşmesidir. İkincisi diyalojik iletişim nesnel gerçeklikle ya da öznellikle değil, öznelerarasılıkla ilgilidir. Diyalojik iletişimin doğası ve tartışılan bir iletişim sürecine vurgu yapması nedeniyle, halkla diyalog halinde olmanın ve halkla ilișkiler yürütmenin etik bir yolu olduğu kabul edilir.

Kent ve Taylor, internetin diyalojik ilişki kurmaya uygun olduğuna vurgu yaparak, kurumsal web sitelerinin hedef kitlelerle diyalojik iletişim kurabilmek için firsat sağladığını ancak, bunu yapabilmek için web sayfalarına diyalojik döngüyü sağlayacak bazı özelliklerin dahil edilmesi gerektiğini söylemektedirler (Kent \& Taylor, 1998, s. 325). Bu bağlamda Kent ve Taylor web sitelerinin diyalojik döngü kapasitesini değerlendiren aşağıdaki beş prensibi tanımlamışlardır (Kent \& Taylor, 1998, s. 326-331);

- Diyalojik Döngü; Web sitelerinin kurumlara sağladığı avantajlardan biri hızlı geri bildirim almaya olanak tanımasıdır. Kurumların hedef kitleleri ile ilişkilerinde geribildirim döngüsü diyalojik iletişimin başlangıç noktası sayılır. Diyalojik bir döngü, hedef kitlenin kuruluşu sorgulamasına izin verir ve daha da önemlisi, halkın merak ettiği, endişe duyduğu ve sorun yaşadığı konularda kuruluşa cevap verme firsatı sunar. Diyalojik döngüyü sağlayabilmek için ziyaretçilerin kuruma mesaj yollayabilmeleri, belli konularda fikirlerini belirtebilmeleri, yorum yapabilmeleri, oy kullanabilmeleri ve bu özelliklerin ve bilgilerin güncel tutulmasının sağlanması gerekir.

- Bilginin Kullanışlı Olması: Web sitesinde yer alan bilgiler, bütün hedef kitlenin ihtiyaçlarına cevap verecek özellikte olmalıdır. Gereksiz süslemelerden, abartılardan kaçınılmalı ve yararlı ve güvenilir bir içeriğe sahip olmalıdır. Web sitesi kurum hakkında, yöneticiler, tarihçe, misyon, vizyon gibi bilgileri de içermelidir. Ziyaretçilerin ihtiyaç duyacağı iletişim adresleri, telefon numaraları, elektronik bilgiler, kuruluş çalışanlarının, uzmanların e-posta adresleri, ürün ya da hizmete ilişkin bilgileri içermeli ve herkes tarafında kolayca erişilebilir olmalıdır. Ziyaretçilere e-posta 
listelerine ve tartışma gruplarına kaydolma fırsatı sunan web siteleri, hedef kitlenin sitelerine gelmesini ve bilgi talep etmesini bekleyen rakip kuruluşların önündedir.

- Yeniden Ziyaretin Sağlanması: Web sitesi güncel bilgiler, değișen konular, özel forumlar, yeni yorumlar, çevrimiçi soru-cevap oturumları ve ilgilenen ziyaretçiler için soruları yanıtlayan çevrimiçi "uzmanlar" gibi tekrar ziyaret etme isteği uyandıracak içeriğe sahip olmalıdır. Sınırlı, standart, klişe ve değişmeyen bilgiler bir kez ziyaretten sonra artık ilgi çekici olmaz. Bilgilerin güncel tutulması güvenilir ve sorumlu bir kuruluş etkisi oluşturur. Etkileşimli forumlar, soru-cevap formatları ve yöneticilerle etkileşim olanakları hedef kitlenin ilgisini çeker. Tekrar ziyaretleri teşvik eden diğer araçlar arasında sık sorulan sorular (SSS'ler), kolayca indirilebilir veya elektronik posta yoluyla talep edilebilecek teknik veya özel bilgiler yer almalıdır.

- Arayüz Kullanım Kolaylığı: Web siteleri ziyaretçiler için kolay anlaşılır ve kullanılabilir iyi organize edilmiş ve hiyerarşik olmalıdır. Kullanıcılar/ziyaretçiler, aradıkları bilgilere ulaşmak için rastgele bağlantıları takip etmek zorunda kalmamalıdırlar. Web siteleri ağırlıklı olarak metinsel olmalı, grafiksel özellikler daha az yer almalıdır. Web siteleri yalnızca ağ yazılımının "en yeni” veya "belirli" sürümlerine sahip kullanıcılar tarafından erişilebilir olacak şekilde tasarlanmamalı, herkesin erişimine uygun olmalıdır.

- Ziyaretçilerin Sitede Kalmasını Sağlama: Web sayfasını tasarlayanların ziyaretçileri yanıltacak ve başka sitelere yönlendirecek bağlantılar konusunda dikkatli olması gerekir. Başka bir siteye yönlendirilen ziyaretçi tekrar siteye dönmeyebilir. Bu nedenle kurumsal web sitelerinde halkla ilişkilerin amacının, kitleleri "eğlendirmek" değil, onlarla ilişkiler oluşturmak ve geliştirmek olduğu unutulmadan web sitelerinin yalnızca gerekli olan temel bağlantıları içermesine dikkat etmek gerekir.

Web siteleri iyi ya da kötü özellikleriyle kurumların görünen pencereleridir (Kent \& Taylor, 1998). Web sitelerinin tasarımı kullanıcının siteye erişimi, kullanım kolaylığı, etkileşimi ve tekrar ziyareti sağlayacak özelliklerin bulunması diyalojik ilişkinin başlaması ve sürdürülmesinde gerekli unsurlardır (Boztepe, 2013, s. 89). Kent ve Taylor'un yukarıda sıralanan prensipleri kurumun ilişki geliştirme hedefleri için web sitelerinin nasıl tasarlanması gerektiği hakkında bir çerçeve sunmaktadır. Web sitelerinin diyaloğa uygunluğunu Kent ve Taylor'ın (1998) diyalojik prensipleri çerçevesinde araştıran bazı çalışmalar şunlardır;

Boztepe (2013) bakanlıkların kurumsal web sayfalarının, diyalojik halkla ilişkiler aracı olarak kullanımına baktığı çalışmasında, kurumsal web sayfalarının diyalojik kapasitelerinden tam anlamıyla faydalanılmadığı sonucuna ulaşmıştır. Özdemir ve Yamanoğlu (2010) Türkiye'deki sivil toplum kuruluşlarının örgüt-kamu ilişkisinin geliştirilmesine yönelik web sitelerini nasıl kullandıklarını araştırmışlardır. Çalışma sonunda web sitelerinin bu ilişkinin geliștirilmesine yönelik diyalojik kapasitelerinin düşük olduğu sonucuna varmışlardır. Güngör ise (2019) Türkiye Yardım Sevenler Derneği'nin web sitesini incelemiş, sitenin daha çok bilgi verme amaçlı kullanıldığı ve diyalojik iletişim kapasitesinin düşük olduğu sonucuna ulaşmıştır. Bu çalışmada büyükșehir belediyelerinin web siteleri Covid-19 salgın sürecinde diyalojik iletişim özellikleri açısından incelenecektir.

\section{Belediyelerde Diyalojik İletişim}

Belediyeler, yerel halkın ortak ihtiyaçlarını karşılamakla sorumlu olan ve kamu hizmeti veren siyasal yönetim birimleridir. Faaliyetlerini halkla iç içe sürdüren belediyeler için yerel halkın beklentilerini karşılayarak onların desteğini almak çok önemlidir. Küreselleşme, bilgi toplumu ve dijitalleşme süreçleri geleneksel yönetim anlayışını 
dönüştürürken belediye-vatandaş ilişkisini ve vatandaşın beklentilerini de etkilemiștir. Artık günümüz vatandaşları belediyeyi ve hizmetlerini sorgulayan, talepte bulunan, kendi yararına politikaların geliştirilmesini ve bazı yönetsel süreçlere dahil edilmeyi bekleyen aktif bireylerdir. Bu vatandaşlar için; çöpünün zamanında alınması, içme suyunun arındırılması, sosyal alanların yapılandırılması, alt yapı çalışmalarının kalitesi kadar; belediyenin aktif ve enerjik çalışması, toplumsal duyarlılığının olması, çözüm odaklı çalışması, kolay erişilebilir olması, yapılan işler hakkında vatandaşa bilgi verilmesi, vatandaşın onayının alınması, başvuruların kolaylaştırılması, istek-ihtiyaç ve taleplerin öğrenilerek vatandaşla etkileșim halinde olunması yani vatandaş katılımının da sağlandığı bir ilişkinin kurulabilmesi önemlidir (Arslan, 2016, s. 81; Türk \& Akçay, 2010, s. 142). Ancak giderek artan nüfus, ihtiyaçların ve hizmetlerin çeşitlenerek çoğalması herkesi ilgilendiren meselelerin yüz yüze görüşülmesini ve katılımın sağlanmasını güçleștirmiştir. Bu engellerin aşılması vatandaşla diyalojik bir ortamın kurularak yerel katılımın artırılması ihtiyacı belediyeleri dijital dünyaya adım atmaya yöneltmiştir (Aslan, 2017, s. 2428).

Belediyeler değişen ve artan vatandaş taleplerini kesintisiz, hızlı, ekonomik, etkili ve güvenilir bir şekilde karşılamak, bürokrasiyi azaltmak, kurumsal tanınırlığı artırmak, vatandaşı ve beklentilerini daha iyi tanımak, belediyenin imaj ve hizmet kalitesini yükseltmek, halkla ilişkiler çalıșmalarını daha etkin hale getirmek ve kamu hizmetlerinin sunumunda etkinliği artırmak için internetin ve web sitelerinin sunduğu fırsatları kullanmaya başlamışlardır (Mecek, 2017, s. 1817). Belediye-vatandaş ilişkisini diyalojik düzleme taşıyacağı varsayılan bu uygulamalar aynı zamanda yerel katılımın ve demokratikleşmenin de göstergeleri olarak kabul edilebilir (Yağmurlu, 2013, s. 111). Web sitelerinin, kurumların hedef kitleleriyle ilişkilerinde diyalog kurmak için çok uygun iletişim araçları olduğunu söyleyen Kent ve Taylor'a (1998) göre aralarında açık bir iletişim kurulabilmesi ve hedef kitlenin farklı ihtiyaçlarına cevap verebilmesi için web sitelerinin diyalojik prensiplere uygun hazırlanmış olması gerekir. Diyalojik özellikleri taşımayan web siteleri ise, genellikle tanıtıma odaklanarak ilişkilerin monolog şeklinde yürütülmesine aracı olurlar. Belediye web sitelerinin diyaloğa uygunluğunu Kent ve Taylor'ın (1998) diyalojik prensipleri çerçevesinde araştıran bazı çalışmalar şunlardır;

Aslan (2017) Türkiye'deki büyükșehir belediyelerinin web sitelerinin diyalojk olup olmadığını sorguladığı çalışmasında, web sitelerinin vatandaşın katılımına yönelik araçları yeterince sunmadıkları, diyalojik iletişim olanaklarının düşük olduğu ve genellikle bilgi yayma amaçlı kullanıldığı sonucuna varmıştır. Türkiye'deki nüfusu en kalabalık olan on ilin belediye web sitelerini, diyalojik prensipler çerçevesinde inceleyen Akgöz ve Engin (2016) ise; araștırmalarında belediye web sitelerinin diyalojik prensiplerin tamamını karşılamadığı ve hedef kitlelerle daha etkin bir iletişim kurulabilmesi için bu eksiklerin tamamlanması gerektiği sonucuna ulaşmıştır.

\section{Covid-19 Salgın Sürecinde Belediye Hizmetleri}

Covid-19 olarak bilinen Koronavirüsün Dünya Sağllk Örgütü tarafından 11 Mart 2020 tarihinde küresel bir salgın olduğunun ilan edilmesiyle tüm dünyada uluslararası, ulusal ve yerel platformlarda salgınla mücadele başlamıștır. Ulusal düzeyde yapılan mücadelede hükümetler ve yerel yönetimler önemli sorumluluklar almışlardır. Özellikle yerel yönetimlerin temel ihtiyaçlar için hızlı ve etkili çözümler geliştirmelerinin önemi bu dönemde bir kez daha anlaşılmıştır. Türkiye'de yerel yönetimlerin Covıd-19 ile mücadele yöntemlerini 30 büyükşehir belediyesinin, internet sitelerini ve dijital kaynaklarını tarayarak incelemiş olan Bilgiç (2020) uluslararası şehir örneklerinde, yerel yönetimlerin 
hizmetlerini genel olarak; süreçle ilgili kamuoyunu bilgilendirme, sosyal destek ve yardım hizmetleri, eğitim, kültür, sanat, moral ve psikolojik destek ve sağlık hizmetlerine destek alanlarında yürüttügünü Türkiye'de ise hizmetlerin; kamuoyunu bilgilendirme ve farkındalık artırma, düzenli aralıklarla dezenfekte ve temizlik çalışmaları, yerli maske üretimi ve dağıtımı, sağlık hizmetlerine yönelik destekler, sosyal yardım ve destek hizmetleri, alınan tedbir ve kısıtlamalara ilişkin denetim çalışmaları, kültür, sanat, spor ve psikolojik destek hizmetleri ve diğer hizmetler başlıkları altında yürütüldüğünü ifade etmiştir.

Toplumsal yaşamın her alanında krize neden olan Covıd-19 salgınında belediyelerin vatandaşla iletişim kurma araçlarından biri de kurumsal web siteleri olmuştur. Seyahat ve sosyalleşmede sınırlar, günlük yaşam aktivitelerinde kısıtlamalar ve sağlıkla ilgili önlemler konusunda sürekli uyarılan halkın belediyenin sorumluluğundaki hizmetlerle ilgili soru, sorun ya da beklentilerini paylaşabileceği en uygun ve ulaşılabilir araçlardan biri web siteleridir. Bu süreçte belediyelerin web sitelerinin bir kriz iletişim aracı olarak kullanılması ve yönetilmesi gerekmiştir. Kriz dönemlerinde web siteleri ulaşılabilir, güncel, süreçle ilişkili, doğru, güvenilir ve diyaloğa açık olmalıdır. Gerekirse süreçle ilgili özel bir web sayfası açılabilir. Örneğin New York Eyalet Yönetimi Covid-19 salgınında gelişmelerin, hizmetlerin ve kısıtlamalarının duyurulduğu özel bir web sayfası açmıștır (Urhan \& Arslankoç, 2021; Bayraktar, 2020). Londra Belediyesi, salgın sürecinde web sayfasını aktif olarak kullanmış, çeşitli linkler aracılığıyla pandemiye ilişkin sürekli bilgilendirme yapmış, düzenlenen formlar aracılığıyla vatandaşın soruları cevaplanmış, hastalığın belirti ve izlenmesiyle ilgili bilgi ve takipler web sitesi aracılığıyla yapılmış, maske kullanımını yaygınlaştırmak için evde maske yapımı videoları hazırlanıp web sayfasında paylaşılmış, sosyal mesafenin nasıl uygulanacağına yönelik görsel rehberler hazırlanmış ve web sayfasından paylaşılmış, Londra merkezindeki işletmelere yönelik istihdam, finansal ve hukuki konulara yönelik destekler konusunda bilgilendirmeler yapılmış, sağlık temalı linklerin içerikleri güncellenmiş, evde izolasyonun neden olduğu yalnızlıkla ilgili destekler web sitesi üzerinden açıklanmış ve zaman zaman belediye başkanının paylaşımlarına yer verilmiştir (Öner, 2020, s. 75-94). Barselona Belediyesi salgın döneminde özel bir internet sayfası hazırlamış ve Sevgili Günlük adı verilen bir bölümde salgın nedeniyle evde kalmak zorunda olan çocukların yaptıkları resimleri ve her türlü aktiviteleri buradan paylaşmalarını sağlamıştır (Bilgiç, 2020, s. 2091). Türkiye'de ise İstanbul Büyükşehir Belediyesi Mart 2020 tarihinde Enstitü İstanbul Covıd-19 Araștırmaları Web Sitesini kurmuş ve dünya kentlerinin salgınla mücadele politikalarını inceleyerek buradan yayınlamıştır (Urhan \& Arslankoç, 2021, s. 963). Aynı șekilde Ankara Büyükşehir Belediyesi de dünya genelinde alınan önlemleri web sitesi üzerinden paylaşmış, Gaziantep Büyükşehir Belediyesi de web sayfasında "Evde Kal Gaziantep" logosuyla, vatandaşları kısıtlı kaldıkları süre boyunca çeşitli online etkinliklere yönlendirmişlerdir. Elbette salgın sürecinin yönetilmesinde ülkelerin farklı politikalarının olduğunu da hatırlamak gerekir. Türkiye'de salgın sürecinin yönetilmesi ve sağlıkla ilişkili tedbir, kısıtlama ve kararların alınması Cumhurbaşkanlığı, Sağlık Bakanlığı ve İçişleri Bakanlığı tarafından kamuoyu ile paylaşılmaktadır. Bu süreçte belediyelerin sorumluluğu salgından korunma yöntemlerini paylaşmak, belediyelerin aldığı önlemleri açıklamak, farkındalık ve hatırlatma çalışmaları yapmak, kamuoyuna bilgilendirme yapmak, belde halkının süreçle ilgili ihtiyaç ve sorunlarına çözüm üretmektir (Bayraktar, 2020). Bunu sağlayabilmek için de vatandaşla her türlü iletişim aracı üzerinden diyalog halinde olmaya devam etmek gerekmektedir. 


\section{Araştırma Yöntemi}

Bu çalıșmada Türkiye'deki 30 büyükșehir belediyesinin (2021) web siteleri, Covid-19 salgın sürecinde, diyalojik iletişim aracı olma özelliklerini taşıyıp taşımadıkları açısından Kent ve Taylor 'un (1998) diyalojik iletişim teorisi bağlamında incelenmiștir. Çalışmada ayrıca büyükşehir belediyeleri web sitelerinin Covid-19 salgınına ait içerikleri de incelenmiştir. 01-31 Mart 2021 tarihleri arasında incelenen web sitelerinde Kent ve Taylor'un aşağıdaki diyalojik iletişim prensiplerine ve araştırmacı tarafından eklenen Covid-19 ile ilgili içeriğin varlığına bakılmıștır;

- Arayüz kullanım kolaylığı,

- Medyaya ve ziyaretçilere yönelik bilgilerin kullanışlılığı,

- Ziyaretçilerin sitede kalmasını sağlama,

- Yeniden ziyaretin sağlanması

- Diyalojik döngü kriterleri

- Covid-19 ile ilgili içerik

Çalışmada araştırmanın örneklemini oluşturan büyükşehir belediyesi web siteleri yukarıdaki 6 kriter ve 44 alt başlıkta incelenmiş, var olan özelliklere "1" evet, var olmayan özelliklere ise " 0 " hayır değeri verilerek frekans analizi yapılmıştır. Çalışma belediye web sitelerinin diyalojik iletişim kapasitelerini Covid-19 salgın sürecinde sorgulaması bakımından benzer çalışmalardan farklıdır.

\section{Çalışmanın Sınırlılığı}

Çalışmanın veri toplama aşaması Covid-19 salgın sürecinin ikinci yılında 1-31 Mart 2021 tarihleri arasındadır. Bu süreç salgının ilk yılında yaşanan belirsizlik, panik, sokağa çıkma yasakları ve diğer kısıtlamaların kısmen azaldığı, aşılama çalışmalarının başladığı ve yeni normale geçişin yaşandığı dönemdir. Web siteleri güncellendiği için salgının ilk dönemlerindeki içeriğe ulaşılamadığından çalışma sonuçları sadece araştırma tarihindeki web içerikleriyle sınırlıdır. Ancak bu çalışmanın yapıldığı dönmede tüm dünyada ve Türkiye'de salgın ve risklerin halen devam ettiğini de belirtmek gerekir.

\section{Bulgular}

Covid-19 salgın sürecinde Türkiye'de bulunan 30 büyükșehir belediyesinin web siteleri, Kent ve Taylor 'un (1998) diyalojik iletişim prensipleri ve Covid-19 salgını hakkındaki içerikleri açısından 6 kriter ve 44 alt başlıkta incelenmiştir.

Büyükşehir belediyeleri web sitelerinin "ara yüz kullanım kolaylığı" temel prensibi; "site haritası", "sitenin geri kalanına yönlendiren ana başlıklar", "arama kutusu", "görsel haritanın açıklayıcılığı”, " kurumun logosu” alt başlıklarından oluşmaktadır. İnceleme sonucunda bu başlıklar içinde "sitenin geri kalanına yönlendirme" ve "kurum logosu" tüm belediye web sitelerinde diyalojik prensiplere uygun bulunmuşken, "site haritası" özelliği sadece $12(\% 40)$ belediyenin web sitesinde yer almaktadır. Web sitelerinde "arama kutusu" $23(\% 76,7)$, "görsel haritanın açıklayıcılığı" ise $25(\% 83,3)$ belediyede mevcuttur (Tablo 1). Bu kriterde tüm büyükşehir belediyelerinin "kurum logosu" gibi tanıtıma odaklı ve görünür olmalarını sağlayacak unsurları kullandıklarını ancak, "site haritası", "arama kutusu" gibi hedef kitlenin sitede gezinmesini kolaylaştıracak özelliklere yer verilmediği görülmektedir.

Web sitelerinde "Bilgilerin Kullanışlılığı" prensibini Kent ve Taylor medya ve halk için ayrı ayrı açıklamıştır. Buna göre "Medya için bilgilerin kullanışlılığı' prensibi; "basın bülteni ve 
basın duyuruları", "konuşmalar", "indirilebilir grafikler”, "basın odası", "ileitişim bilgileri”, "belediye meclisi" alt başlıklarından oluşmaktdır. Bu başlıklarda yapılan incelemede "iletişim bilgileri" ve "belediye meclisi" alt başlıkları tüm belediyelerde mevcut iken, "basın odası" sadece $8(\% 26,7)$ büyükșehir belediye web sayfasında bulunmaktadır (Tablo 1). Oysa web siteleri kurumlara kendilerini basın gibi dış paydaşlara tanıtmak amacıyla birçok firsat sunmaktadır. Ancak büyükşehir belediyelerinin bu firsatları değerlendiremedikleri görülmektedir.

Bilgilerin kullanışlılığı prensibi "ziyaretçiler için" incelendiğinde; "kurumsal felsefe/ vizyon/misyon", "belediye hizmetlerine ilişkin bilgiler", "güncel duyurular", "belediyeye bağlı diğer linklere yönlendirme", "e-belediye", "dil seçenekleri", "engelli hizmetleri”, "çocuk bölümü", "turistlere yönelik bilgiler" alt başlıkları sorgulanmıştır. Buna göre "belediye hizmetlerine ilişkin bilgiler", "güncel duyurular", "belediyeye bağlı diğer linklere yönlendirme", "e-belediye" ve "turistlere yönelk bilgiler" tüm web sitelerinde diyalojik prensiplere uygun bulunmuşken, "dil seçenekleri" $7(\% 23,3)$ ve "çocuk bölümü" 11 $(\% 36,7)$ belediye web sitesinde mevcuttur (Tablo 1). Bu bulgulara göre ziyaretçiler için bilgilerin kullanışlılığı prensibinde de web siteleri tanıtıma yönelik içeriğin sunulmasında başarılı, ancak dil seçenekleri ve çocuklarla ilgili bölümler gibi farklı hedef kitlelere ulaşmayı sağlayacak özelliklerin sunulması açısından zayıf bulunmuştur.

"Ziyaretçilerin sitede kalmasını sağlama” prensibi; "ana sayfada önemli bilgilerin olması", "sayfanın kısa sürede yüklenmesi", "son dakika güncel bilgilerin yüklenmesi, "son 30 güne ait haberler, kamusal bilgiler" alt başlıklarından oluşmuştur. Büyükşehir belediyeleri web sitelerinin diyalojik özellikler bakımından en başarılı olanı "ziyaretçilerin sitede kalmasını sağlama" prensibidir. 30 büyükşehir belediye web sitesinin hepsinde bu özellikler mevcuttur (Tablo 1). İncelenen büyükșehir belediyeleri web sitelerinin, kısa sürede yüklendiği, ana sayfada belediyenin gündem konularının yer aldığı ve güncel bilgilerin sunulduğu bu özelliklerin de ziyaretçilerin site kalmasında etkili olacağ düşünülmektedir.

Diyalojik prensipler içinde "yeniden ziyaretin sağlanması" kriteri; "sosyal medya hesapları", "güncel haber forumları", "sık sorulan sorular, "diğer web sitelerine link", "etkinlik takvimi", "indirilebilir bilgiler", "düzenli bilgi aboneliği" alt başlıklarından oluşmaktadır. Bu kriterin en başarılı alt basamakları "sosyal medya hesapları" ve indirilebilir bilgiler" dir. Bu iki alt basamak tüm web sitelerinde vardır. Bu prensibin en düşük alt başlığı ise 7 (\%30) belediyede "düzenli bilgi aboneliği" ve $9(\% 23,3)$ belediyede "sık sorulan sorular" alt başlıkları olmuştur (Tablo 1). Bu kriterin alt başlıklarından düzenli bilgi aboneliği ve sık sorulan sorular hedef kitlenin bilgi ihtiyacını karşılamaya yönelik bölümlerdir ve belediye web sayfaları bu başlıklarda oldukça yetersizdir.

"Diyalojik döngü" prensibi; "kullanıcılara yorum yapma imkânı", "konular hakkında oylama yapma fırsatı", "anketler", "e-mail yoluyla bilgi alma", "çevrimiçi yardım imkânı" alt başlıklarından oluşmaktadır. Genel olarak diyalojik iletişim prensipleri içinde web sayfalarının en zayıf olduğu kriterdir. Kullanıcılara yorum yapma imkânı", 1 (\%3,3) web sitesinde, "konular hakkında oylama yapma fırsatı" $1(\% 3,3)$ web sitesinde, çevrimiçi yardım imkânı $3(\% 10)$ sitede, anket ise $7(\% 23,3)$ web sitesinde bulunmaktadır. "Diyalojik döngü" prensibinin en güçlü alt basamağı "e-mail yoluyla bilgi alma özelliği" bütün belediye web sitelerinde mevcuttur (Tablo 1). Diyalojik prensipler içinde hedef kitle ile etkileşimi ölçen bu kritere göre büyükşehir belediyelerinin web siteleri diyalojik özellikler açısından yetersizdir. İncelenen 30 büyükşehir belediyesinin web sitelerinde 
kendi faaliyetlerini tanıtan, anlatan içerikleri aktif olarak kullandıkları ancak; hizmet verdikleri halkı tanımak, beklentilerini, isteklerini, düşüncelerini öğrenmek, katılımlarını teşvik etmek için kullanılabilecek diyalojik uygulamalarının yetersiz olduğu görülmüştür.

Tablo 1. Büyükşehir Belediyeleri Web Sitelerinin Diyalojik İletişim Özellikleri

\begin{tabular}{|c|c|c|c|c|c|}
\hline & \multirow{2}{*}{\begin{tabular}{|l|} 
Diyalojik Özellikler \\
Arayüz Kulanım Kolaylığı \\
\end{tabular}} & \multicolumn{2}{|c|}{ Evet } & \multicolumn{2}{|c|}{ Hayır } \\
\hline & & Sayı & Yüzde & Sayı & Yüzde \\
\hline 1 & Site haritası & 12 & $\% 40$ & 18 & $\% 60$ \\
\hline 2 & Sitenin geri kalanına yönlendiren ana başlıklar & 30 & $\% 100$ & 0 & $\% 0$ \\
\hline 3 & Arama kutusu & 23 & $\% 76,7$ & 7 & $\% 23,3$ \\
\hline 4 & Görsel haritanın açıklayıcılığı & 25 & $\% 83,3$ & 5 & $\% 16,7$ \\
\hline \multirow[t]{2}{*}{5} & Kurumun logosu & 30 & $\% 100$ & 0 & $\% 0$ \\
\hline & Bilgilerin Kullanışılığı -Medya İçin & Sayı & Yüzde & Sayı & Yüzde \\
\hline 6 & Basın bülteni ve basın duyuruları & 12 & $\% 40$ & 18 & $\% 60$ \\
\hline 7 & Konuşmalar & 11 & $\% 36,7$ & 19 & $\% 63,3$ \\
\hline 8 & İndirilebilir grafikler & 25 & $\% 83,3$ & 5 & $\% 16,7$ \\
\hline 9 & Basın odası & 8 & $\% 26,7$ & 22 & $\% 73,3$ \\
\hline 10 & İletişim bilgileri & 30 & $\% 100$ & 0 & $\% 0$ \\
\hline \multirow[t]{2}{*}{11} & Belediye meclisi & 30 & $\% 100$ & 0 & $\% 0$ \\
\hline & Bilgilerin Kullanışııı̆ı Ziyaretçiler İçin & Sayı & Yüzde & Sayı & Yüzde \\
\hline 12 & Kurumsal felsefe/vizyon/misyon & 26 & $\% 86,7$ & 4 & $\% 13,3$ \\
\hline 13 & Belediye hizmetlerine ilişkin bilgiler & 30 & $\% 100$ & 0 & $\% 0$ \\
\hline 14 & Güncel duyurular & 30 & $\% 100$ & 0 & $\% 0$ \\
\hline 15 & Belediyeye bağlı diğer linklere yönlendirme & 30 & $\% 100$ & 0 & $\% 0$ \\
\hline 16 & E-belediye & 30 & $\% 100$ & 0 & $\% 0$ \\
\hline 17 & Dil seçenekleri & 7 & $\% 23,3$ & 23 & $\% 76,7$ \\
\hline 18 & Engelli hizmetleri & 27 & $\% 90,0$ & 3 & $\% 10,0$ \\
\hline 19 & Çocuk Bölümü & 11 & $\% 36,7$ & 19 & $\% 63,3$ \\
\hline \multirow[t]{2}{*}{20} & Turistlere yönelik bilgiler & 30 & $\% 100$ & 0 & $\% 0$ \\
\hline & Ziyaretçilerin Sitede Kalmasını Sağlama & Sayı & Yüzde & Sayı & Yüzde \\
\hline 21 & Ana sayfadai önemli bilgilerin olması & 30 & $\% 100$ & 0 & $\% 0$ \\
\hline 22 & Sayfanın kısa sürede yüklenmesi & 30 & $\% 100$ & 0 & $\% 0$ \\
\hline 23 & Son dakika güncel bilgilerin yüklenmesi & 30 & $\% 100$ & 0 & $\% 0$ \\
\hline \multirow[t]{2}{*}{24} & Son 30 güne ait haberler, kamusal bilgiler & 30 & $\% 100$ & 0 & $\% 0$ \\
\hline & Yeniden Ziyaretin Sağlanması & Sayı & Ytizde & Sayı & Yüzde \\
\hline 25 & Sosyal medya hesapları & 30 & $\% 100$ & 0 & $\% 0$ \\
\hline 26 & Güncel haber forumları & 22 & $\% 73,3$ & 8 & $\% 26,7$ \\
\hline 27 & Sık sorulan sorular & 9 & $\% 30,0$ & 21 & $\% 70,0$ \\
\hline 28 & Diğer web sitelerine link & 28 & $\% 93,3$ & 2 & $\% 6,7$ \\
\hline 29 & Etkinlik takvimi & 27 & $\% 90,0$ & 3 & $\% 10,0$ \\
\hline 30 & İndirilebilir bilgiler & 30 & $\% 100$ & 0 & $\% 0$ \\
\hline \multirow[t]{2}{*}{31} & Düzenli bilgi aboneliği & 7 & $\% 23,3$ & 23 & $\% 76,7$ \\
\hline & Diyalojik Döngü & Sayı & Ytizde & Sayı & Yüzde \\
\hline 32 & Kullanıcılara yorum yapma imkânı & 1 & $\% 3,3$ & 29 & $\% 96,7$ \\
\hline 33 & Konular hakkında oylama yapma fırsatı & 1 & $\% 3,3$ & 29 & $\% 96,7$ \\
\hline 34 & Anketler & 7 & $\% 23,3$ & 23 & $\% 76,7$ \\
\hline 35 & E mail yoluyla bilgi alma & 30 & $\% 100$ & 0 & $\% 0$ \\
\hline 36 & Çevrimiçi yardım imkânı & 3 & $\% 10,0$ & 27 & $\% 90$ \\
\hline
\end{tabular}

"Büyükșehir belediyeleri web sitelerinin Covid-19 salgınına ait içerikleri" başlığı altında; 
"ana sayfada Covid-19 farkındalığı ile ilgili mesaj, logo", "ana sayfada Covid-19 ile ilișkili bilgilendirme", "Covid-19 hakkında bir link", "Covid-19 hakkında bir sayfa", "Covid-19 bilgilerinin güncelliği", “Covid-19 süreciyle ilişkili etkinlikler”, "Covid-19 içerikli haberler”, "Covid-19 konusunda diyalojik döngü özellikleri” alt başlıkları yer almaktadır. Bu alt başlıklarda büyükşehir belediye web sitelerinin genel içeriklerinden farklı olarak sadece Covid-19'la ilişkili yani kriz durumuna özel bir uygulama ve içeriğin varlığına bakılmıştır. Bu başlık altında en zayıf özellik "Covid-19 konusunda diyalojik döngü özellikleri" alt başlığı olmuştur. Bu alt başlıkta hedef kitle ile Covid-19 konusunda etkileşime izin veren bir uygulamanın olup olmadığına bakılmıştır. Belediye web sitelerinin hiçbirinde bu özellik bulunmamaktadır. "Covid-19 hakkında bir sayfa" alt başlığında belediye web sitelerinde kurumun kendisinin oluşturduğu özel bir sayfa olup olmadığına bakılmış ve $2(\% 6,7)$ belediyede Covid-19 süreciyle ilgili bir sayfanın hazırlandığı görülmüştür. 5 $(\% 16,7)$ belediye web sayfasında ise Covid-19 ya da koronavirüs ifadelerini içeren bir link ile Sağlık Bakanlığı web sitesine yönlendirme vardır. "Ana sayfada Covid-19 farkındalı̆̆ ile ilgili mesaj logo" alt başlığında 3 (\%10) belediyenin web sitesinde logo şeklinde farkındalık mesajına rastlanmıştır. "Ana sayfada Covid-19 ile ilișkili bilgilendirme" alt başlığında, herhangi bir uyarı, yönlendirme ya da salgınla ilgili bir bilginin varlığına bakılmış $7(\% 23,3)$ belediye web sitesinde bu özelliğin olduğu tespit edilmiştir. "Covid-19 bilgilerinin güncelliği" başlığında ise $7(\% 23,3)$ belediye web sitesinde bilgilerin güncel tutulduğu görülmüştür. "Covid-19 süreciyle ilişkili etkinlikler" alt başlığında belediyelerin salgın sürecinde düzenledikleri çeşitli belediye hizmetleri, sosyal yardımlar, eğitim, sanat, kültür, spor faaliyetlerinin varlığına bakılmış ve $16(\% 53,3)$ belediye web sayfasında bu bilgiler tespit edilmiştir. "Büyükşehir belediyeleri web sitelerinin Covid-19 salgınına ait içerikleri" başlığı altındaki en başarılı alt başlık "Covid-19 içerikli haberler" olmuştur. Bütün belediyelerin haber arşivlerinde konuyla ilgili süreç boyunca gerçekleştirilen faaliyetlerin haberleri mevcuttur (Tablo 2). Yapllan incelemede web sitelerinin birçoğunda salgın süreciyle ilgili içeriğin arşiv haberlerinden ya da "HES Kodu" sorgulamaya yönelik resmi bilgilendirmelerden oluştuğu görülmüștür. Oysa çalışmanın yapıldığı dönemde salgın süreci devam etmektedir ve yetkili makamlar süreçle ilgili tedbirlerin, uygulanması ve takip edilmesi konusunda sürekli uyarılarda bulunmaktadırlar. Belediyelerin web sitelerinde bu uyarılara ve salgınla ilgili farkındalığı artıracak içeriklere yer vererek, her türlü iletişim aracı üzerinden halkla diyalog halinde olmaları gerekmektedir.

Tablo 2. Büyükşehir Belediyeleri Web Sitelerinin Covid-19 Salgınına Ait İçerikleri

\begin{tabular}{|l|l|c|c|c|c|}
\hline & & \multicolumn{2}{|c|}{ Evet } & \multicolumn{2}{c|}{ Hayır } \\
\hline & Web Sayfalarında Covid-19 & Sayı & Yüzde & Sayı & Yüzde \\
\hline 37 & Ana sayfada Covid-19 farkındalı̆̆ı ile ilgili mesaj logo & 3 & $\% 10$ & 27 & $\% 90$ \\
\hline 38 & Ana sayfada Covid-19 ile ilişkili bilgilendirme & 7 & $\% 23,3$ & 23 & $\% 76,7$ \\
\hline 39 & Covid-19 hakkında bir link & 5 & $\% 16,7$ & 25 & $\% 83,3$ \\
\hline 40 & Covid-19 hakkında bir sayfa & 2 & $\% 6,7$ & 28 & $\% 93,3$ \\
\hline 41 & Covid-19 bilgilerinin güncelliği & 7 & $\% 23,3$ & 23 & $\% 76,7$ \\
\hline 42 & Covid-19 süreciyle ilişkili etkinlikler & 16 & $\% 53,3$ & 14 & $\% 46,7$ \\
\hline 43 & Covid-19 içerikli haberler & 30 & $\% 100$ & 0 & $\% 0$ \\
\hline 44 & Covid-19 konusunda diyalojik döngü özellikleri & 0 & $\% 0$ & 30 & $\% 100$ \\
\hline
\end{tabular}

\section{Sonuç}

Diyalojik yaklaşım, kurum ve hedef kitleleri arasında karşılıklı anlayış, iyi niyet ve güvene dayalı bir ilişkinin geliştirilebilmesini sağlayacak en uygun halkla ilişkiler yaklaşımlarından biridir. Diyalojik ilişkinin kurulması, kamu kategorilerinin örgütle iletişimsel anlamda eșit 
duruma gelmesini ve daha katılımcı, demokratik bir ortamın oluşmasını sağlar. Günümüz insanlarının kurumlardan beklentisi de bu yöndedir. İçinde bulunduğumuz çağda birçok dijital araç ve uygulama kurumlara hedef kitleleriyle diyalojik iletişim kurma firsatı sunar. Kurumsal web siteleri en yaygın kullanılan dijital uygulamalar arasındadır (Bayrak, 2021). Kent ve Taylor, web sitelerinin diyalojik iletişim kurmak için çok uygun araçlar olduğunu, ancak, bunu yapabilmek için web sayfalarına diyalojik döngüyü sağlayacak bazı özelliklerin dahil edilmesi gerektiğini belirterek, bu özellikleri tanımladıkları bir çerçeve sunmuşlardır. Bu çalışmada büyükşehir belediyeleri web sitelerinin, Covid-19 salgın sürecinde, diyalojik iletişim aracı olma özelliklerini taşıyıp taşımadıkları Kent ve Taylor "un "arayüz kullanım kolaylığı", "medyaya ve ziyaretçilere yönelik bilgilerin kullanışlılığı", "ziyaretçilerin sitede kalmasını sağlama”, "yeniden ziyaretin sağlanması" ve "diyalojik döngü" prensiplerine göre incelenmiştir. Ayrıca web sitelerinde yer alan Covid-19 salgın sürecine ait içerikler de incelenmiştir.

Çalışmanın sonucunda elde edilen bulgular belediye web sitelerinde en güçlü kriterin "ziyaretçilerin sitede kalmasını sağlama", en zayıf kriterin ise "diyalojik döngü" olduğunu göstermiştir. Büyükşehir belediyeleri web sitelerinde çoğunlukla kurumların yönetimini, hizmetlerini, planlamalarını, faaliyetlerini kapsayan tanıtıma yönelik içeriğe yer verildiği; buna karşılık kullanıcılara yorum yapma imkânı, anket, çevrimiçi yardım imkânı, konular hakkında oylama yapma fırsatı gibi etkileşimi sağlayacak özelliklerin çok az olduğu görülmüştür. Bu sonuçlar Engin ve Akgöz'ün (2016) ve Aslan'ın (2017) benzer çalışmalarının bulgularıyla da uyumludur. Web sitelerinin Covid-19 içeriklerine bakıldığında ise, çoğunlukla belediyelerin salgınla ilgili faaliyetlerinin haber olarak yer aldığı ve bazı belediyelerin halen devam eden vatandaşa destek kampanyalarının ve çeşitli sosyal, kültürel etkinliklerinin sayfalarda yer aldığı görülmektedir. Tüm dünyada benzeri görülmemiş bir durumun yaşandığı ve mücadelenin halen devam ettiği bir süreçte belediye web sayfalarında farkındalık mesajları, korunma yöntemleri ya da salgınla ilgili linkler çok az sayıdadır. Covid-19 ile ilgili diyalojik döngü özellikleri ise hiçbir web sitesinde yer almamaktadır. Elbette ülkemizde salgın sürecinin yönetilmesi ve sağlıkla ilişkili tedbir, kısıtlama ve kararların alınması belediyelerin sorumluluğunda değildir. Ancak tüm dünyayı etkisi altına alan ve eși benzeri görülmeyen bu salgın sürecinde yerel yönetimlere de önemli sorumluluklar yüklenmiştir. Belde halkıyla salgından korunma yöntemlerini paylaşmak, belediyelerin aldığı önlemleri açıklamak, farkındalık ve hatırlatma çalışmaları yapmak, kamuoyuna bilgilendirme yapmak, belde halkının süreçle ilgili sorunlarına çözüm üretmek bunun için de diyalojik ilişkiyi sağlayacak her türlü uygulamayı aktif tutmak gerekir. Belediyeler kriz sürecinde vatandaşın yanında olduklarını her ortamda gösterebilmelidirler. Bunun için web siteleri dahil her türlü diyalojik uygulamanın devreye sokulmuş olması gerekmektedir. Özellikle kriz döneminde web sitelerinin daha önceki çalıșmalarla da saptanmış olan eksikliklerinin tamamlanmış olması ve diyalojik araç ve uygulamaların eklenerek aktifleştirilmesi etkili kriz yönetimi için yapılması gereken uygulamalardır. Kriz dönemlerinde vatandaşla kurulan iletişimde, etkileşimin güçlü olması krizin daha az hasarla atlatılmasını ve kamuoyunun güveninin kazanılmasını sağlamaktadır.

Tehlikenin henüz geçmediği, salgının halen devam ettiği bu dönemde büyükşehir belediyelerinin web sitelerini tekrar gözden geçirerek vatandaşla etkileşime firsat sağlayan diyalojik döngü özelliklerindeki eksiklerini gidermeleri ve salgınla mücadelede web sitelerinden bilgilendirme, uyarı, hatırlatma sorumluluklarının devam ettirilmesi önerilmektedir. 


\section{Kaynakça}

Akdağ, M., \& Taşdemir, E. (2006). Krizden Çıkmanın Yolları: Etkin Bir Kriz İletişimi. Selçuk İletişim, 4(2), 141-157.

Akyıldız, F. (2012). Belediye Hizmetleri ve Vatandaş Memnuniyeti: Uşak Belediyesi Örneği. Journal of Yasar University, 26(7), 4415-4436.

Arslan, A. (2016). Belediyelerde Kurum İmajı. Bursa: Ekin Yayıncılık.

Aslan, A. (2017). Web Sitelerinin Birer Diyalojik İletişim Aracı Olarak Kullanımı Üzerine Bir Değerlendirme: Türkiye'deki Büyükşehir Belediyeleri Örneği. Süleyman Demirel İktisadi ve Ídari Bilimler Dergisi, 22(Kayfor15 Özel Sayısı), 2425-2436.

Bayrak, H. (2021). Hootsuite ve We Are Social 2021 Dijital Türkiye Raporu. 09 08, 2021 tarihinde https://dijilopedi.com/turkiye-internet-sosyal-medya-ve-mobilkullanim-istatistikleri-2021/ adresinden alındı

Bayraktar, U. (2020). Pandemide ve Sonrasında Yerel Yönetimler İçin Politika Önerileri. İstanpol: https://www.istanpol.org/post/pandemide-ve-sonras\%C4\%B1ndayerel-y\%C3\%B6netimler-i\%CC\%87\%C3\%A7in-politika-\%C3\%B6nerileri adresinden alınmıştır

Bilgiç, A. K. (2020). COVID-19 ile Mücadele Sürecind eYerel Yönetimlerin Genel Görünümü. Kent Araştırmaları Dergisi, 11(31), 2084-2112.

Boztepe, H. (2013). Halkla İlişkilerin Kurum ile Hedef Kitle Arasında İlişki Oluşturma Amacı ve Kurumsal Web Sayfalarının Diyalojik Halkla İlişkiler Aracı Olarak Kullanımı. Akdeniz İletişim Dergisi(20), 86-104.

Camilleri, M. A. (2021). Strategic dialogic communication through digital media during COVID-19 crisis. M. A. Camilleri içinde, Strategic Corporate Communication in the Digital Age (s. 1-19). Bingley, UK.: Emerald.

Cavalic, A. (2017). Crisıs Communicatıon And The Internet. 4th International Scientific Conference "Economy of Integration". Tuzla: University of Tuzla Faculty of Economics.

Çarıkçı, O. (2010). Türkiye`de E-Devlet Uygulamaları Üzerine Bir Araştırma. Süleyman Demirel Üniversitesi Sosyal Bilimler Enstitüsü Dergisi, 2(12), 95-122.

Dunleavy, P., Margetts, H., John, S., \& McCarthy, D. (1999). Government on the Web. London: The Stationery Office.

Engin, E., \& Akgöz, B. E. (2016). Belediyelerin Web Sitelerinin Diyalojik İletişim Açısından Analizi. Atatürk İletişim Dergisi, 10(Ocak), 91-110.

Fogli, D., \& Guida, G. (2015). A practical approach to the assessment of quality in use ofcorporate web sites. The Journal of Systems and Software(99), 52-65.

Grier, C. F., \& Moreland, K. d. (2003). United Airlines' and American Airlines' online crisis communication following the September 11 terrorist attacks. Public Relations Review, 29(4), 427-441.

Güçdemir, Y. (2010). Sanal Ortamda iletişim bir Halkla İlişkiler Perspektifi. İstanbul: Derin Yayınları.

Güngör, F. S. (2019). Diyalojik İletişim ve Sivil Toplum Örgütlerinin Web Siteleri: Cumhuriyetin İlk Sivil Toplum Kuruluşu “Türkiye Yardım Sevenler Derneği” Web Sitesi Değerlendirmesi. Başkent Üniversitesi Ticari Bilimler Dergisi, 3(2), 25-43. 
Karataş, E., \& Tarhan, A. (2021). Yerel Yönetimlerde E-Belediye Uygulamaları: Büyükşehir. Selçuk Üniversitesi Sosyal Bilimler Enstitüsü Dergisi, 317-335.

Kent, M. L., \& Taylor, M. (1998). Building a dialogic relationship through the World Wide. Public Relations Review(24), 321-334.

Kent, M. L., \& Taylor, M. (2002). Toward a dialogic theory of public relations. Public Relations Review, 21-37.

Kent, M. L., Taylor, M., \& White, W. J. (2003). The relationship between Web site design and. Public Relations Review(29), 63-77.

Kılıçer, K. (2018). Web Teknolojisinin Doğuşu ve Gelişimi. Y. L. Şahin içinde, Web Tabanlı Kodlama. Eskişehir: TC Anadolu Üniversitesi Yayını.

Mecek, M. (2017). E-Devlet ve E-Belediye: Kavramsal Çerçeve ve Türkiye'de Belediye Web Sitelerine Yönelik Yapılan Çalıșmaların İncelenmesi. Süleyman Demirel Üniversitesi Íktisadi ve İdari Bilimler Fakültesi Dergisi, 22( Kayfor15 Özel Sayısı), 1815-1851.

Mengü, S. Ç. (2016). Kurumsal İletişim ve Profesyonel Markalar. İstanbul: Der Yayınları.

Öner, Ş. (2020). Küresel Pandemi (COVID-19) ve Kent Yönetimlerinin Tepkisi:Londra Belediyesi Örneği. Sosyal Bilimler Araştırma Dergisi, 9(4), 75-94.

Özdemir, B., \& Yamanoğlu, M. A. (2010). Türkiye`deki Sivil Toplum Kuruluşları Web Sitelerinin Diyalojik İletișim Kapasitelerine Göre Bir İnceleme. Ankara Üniversitesi Sosyal Bilimler Enstitüsü Dergisi, 1(2), 3-36.

Peltekoğlu, F. B. (2007). Halkla İlişkiler Nedir? İstanbul: Beta Yayınevi.

Pollach, I. (2005). Corporate self-presentation on the WWW. Corporate Communications: An International Journal, 1(4), 285-301.

Pollach, I. (2011). The Readershıp Of Corporate Websites. Journal of Business Communication, 48(1), 27-53.

Tarhan, A. (2011). Kamu Yönetiminde Halkla İlişkiler ve E-Devlet. Konya: Palet Yayınları.

Total number of Websites. (2021). internet live stats: https://www.internetlivestats.com/ adresinden alınmıştır

Türk, S., \& Akçay, H. (2010). Yerel Yönetimlerde Halkla İlişkiler Faaliyetlerinin Kurum İmajına Etkisi Üzerine Bir Çalışma: Trabzon Belediyesi. Gazi Üniversitesi İletişim Fakültesi(31), 141-180.

Türkiye Belediyeler Birliği. (2021). Genel İstatistikler. Türkiye Belediyeler Birliği: https:// www.tbb.gov.tr/belediyelerimiz/istatistikler/genel-istatistikler/ adresinden alınmıştır

Urhan, G., \& Arslankoç, S. (2021). COVID-19 Pandemi Sürecinde Sosyal Politika ve Yerel Yönetimler: İstanbul İlçe Belediyeleri Örneği. Çalışma ve Toplum,(2), 945-980.

Yağmurlu, A. (2013). Diyalojik İletişim Çerçevesinden Ankara Büyükşehir Belediyesi. Selçuk İletişim, 8(1), 95-115.

Yaşar, İ. H., \& Altıncık, H. (2018). Türkiye Cumhuriyeti Bakanlıklarının web sitelerinin halkla ilişkiler bağlamında değerlendirilmesi. Dumlupınar Üniversitesi Sosyal Bilimler Dergisi(55), 224-236. 


\title{
Evaluation of Metropolitan Municipalities' Websites in terms of Dialogic Communication during the Covid-19 Pandemic
}

\author{
Aynur Arslan (Asst. Prof. Dr.)
}

\section{Extended Abstract}

Today, municipal-citizen communication reached a digital level through corporate websites. Municipalities can communicate with the target groups whose numbers and expectations increase and change, more quickly, easily and effectively through websites, provide information about corporate publicity, services and activities, and provide many services safely in digital environment with e-municipal applications. The websites also offer a dialogic environment in which citizens can communicate their problems, demands, expectations, preferences and opinions to the municipality. The success of municipalities depends on how much they know the people they serve and the power of interaction. The importance of local measures to fight the rapidly spreading Covid-19 pandemic, declared as global epidemic by World Health Organization on March 11, 2020 has become prominent and the responsibilities of municipalities, local administration units, have also increased. Providing solutions to many needs of citizens who have to stay at home due to the pandemic and are blocked due to various restrictions, especially health, education, social assistance, nutrition, cleaning, as well as support for the implementation of measures taken to prevent the spread of the pandemic. Web-sites are one of the fastest and easiest ways to reach municipalities for citizens during this time. One of the most strategic usage areas of corporate websites is such crisis situations. Websites are effective communication tools for emergency and first responders in crisis situations. In crisis situations, organizations should primarily use their websites as the central platform for crisis communication. Because, the first address of the users looking for information in times of crisis is corporate websites. It is an advantage for the organization as it is prepared by the organization and the content is controlled, allowing the creation of verifiable sources of information for both the general public and the media.

The aim of the study is to demonstrate how metropolitan municipalities in Turkey used websites as a dialogic communication tool to interact with their target audience and develop relationships during the covid-19 pandemic. For this purpose, 30 metropolitan municipalities in Turkey were examined between March 1-31, 2021, in the context of Kent and Taylor's dialogic communication theory (1998). Kent and Taylor emphasized that the internet and websites are suitable for establishing dialogic relationships. They stated that corporate websites provide an opportunity to communicate dialogically with stakeholders, but in order to do this, some features that will provide a dialogic loop should be included in the web pages. In this context, Kent and Taylor defined the following five principles that assess the dialogic loop capacity of websites. While the websites are being examined in the study, we analyzed them according to Kent and Taylor's dialogic principles "ease of interface", "usefulness of information for media and visitors/volunteers", "conservation of visitors", "generation of return visits" and "dialogic loop", as well as content related to Covid-19 on municipalities' web pages. Thus, websites were examined according to 6 criteria and under 44 subheads. In the study, frequency analysis was carried out by giving "1" "yes" to existing properties and "0" "No" to nonexisting properties. 
The results of the study showed that the strongest criterion on municipalities' websites was "conservation of visitors", and the weakest one was "dialogic loop". It has been observed that metropolitan municipalities' websites mostly contain promotional content including the management, services, planning, activities of institutions. On the other hand, there are very few features that will allow users to interact, such as commenting, attending to surveys, online help system, and voting on topics. As for the websites' contents related to the Covid-19, it has been seen that the municipalities' pandemic-related activities were appeared mostly as a news story, and some municipalities' ongoing campaigns supporting citizens and several social, cultural activities appeared on web pages. At a time when there is an unprecedented situation around the world and the struggle is still ongoing, awareness messages, prevention methods or links to the pandemic are very few on municipalities' web pages. There are no dialogic loops related to Covid-19 on websites. In the contacts made with the citizen in times of crisis, strong interaction allows the crisis to be overcome with the least amount of damage and gain public confidence. During this period, when the danger is not over and the pandemic is still ongoing, it is recommended to review the websites of metropolitan municipalities and eliminate the deficiencies of the dialogic loop characteristics that provide the opportunity to interact with the citizen.

Keywords: Public Relations, Metropolitan Municipalities, Corporate Websites, Dialogic Communication, Covid-19 Pandemic.

Bu makale intihal tespit yazılımlarıyla taranmıştır. Intihal tespit edilmemiştir.

This article has been scanned by plagiarism detection softwares. No plagiarism detected.

Bu çalışmada "Yükseköğretim Kurumları Bilimsel Araştırma ve Yayın Etiği Yönergesi” kapsamında uyulması belirtilen kurallara uyulmuştur.

In this study, the rules stated in the "Higher Education Institutions Scientific Research and Publication Ethics Directive" were followed.

Çalışma tek bir yazar tarafından yürütülmüştür.

The study was conducted by one author.

Çalışma kapsamında herhangi bir kurum veya kişi ile çıkar çatışması bulunmamaktadır.

There is no conflict of interest with any institution or person within the scope of the study. 